\title{
Japan and the 'Flying Geese' Pattern of East Asian Integration
}

\author{
by Fumitaka Furuoka $\square$
}

In this paper uses Kaname Akamatsu's 'Flying Geese' model to analyse Japan's role in East Asian integration. Japan made the first attempt to lead Asian countries before the Second World War. At that time, the Japanese Government embarked on a brutally expansionist policy the result of which was creation of the first gaggle of 'flying geese' under the name of the 'Greater East Asia CoProsperity Sphere.' During the 'flight' Japan was forcefully imposing its own ideals and values on the rest of the 'gaggle.' At the same time, the Japanese Government assumed hostile attitude toward Western countries. Japan's defeat in the Second World War signified the end of flight for the first 'flying geese' gaggle. After the war, Japan made another attempt at regional integration. This time it was done through establishing a production network in East Asia. Thus the second gaggle of 'flying geese' came into existence. During the flight of the 'second gaggle' of geese, Japan was fostering good ties with Western countries as well, especially the United States. However, some leaders of the 'second gaggle's' member-countries emboldened by their countries' economic success proclaimed that future belongs to Asia and put forward the 'Asian values' argument. The Asian economic crisis of 1997 interrupted the flight of the 'second gaggle' and effectively put an end to the 'Asian values' debate. It is interesting to note that some elements of the 'Asian values' argument resembled ultranationalist discourse that had been dominant in Japan before and during the Second World War. This paper compares historical patterns of East Asian regional integration and highlights future challenges for Japan's Asia policy.

\section{Introduction}

Japan is the first Asian country that successfully industrialized its economy and became economically on a par with advanced Western countries. After the opening to the West in the middle of the nineteenth century, Japan was striving to build a prosperous economy and powerful military in order to survive the harsh reality of imperialism. Leaders of the Meiji Restoration of 1868 grew increasingly nationalist when observing East Asian countries, including Japan's giant neighbour, China, colonized by Western countries.[i] To avoid China's and other Asian countries' fate and in order to be able to compete on equal terms with Western countries, Japanese political elite recognized the necessity to overcome what it described socio-economic and cultural backwardness as an Asian country. To achieve this target, a slogan 'Escape from Asia and Enter Europe' (Datsu-a, Nyu-o) was introduced.

Japan's attempt to catch up with Western countries was interrupted by a self-destructive war that Japan waged against the Allies. Japan lost the war and in 1945 declared its unconditional surrender to the Allies. After the war, the Japanese Government's top priority was rehabilitating the country's economy. For this, all available resources were invested into several key industries that produced exportable manufactures and brought in the much needed foreign currency revenues.

Rising from ashes, Japan achieved high economic growth in the 1950s and 1960s. By the middle of the 1970s, Japan became the second largest economy in the world. Japan's single-minded determination to join 'rich countries clubs' that were largely dominated by Western countries eventually bore fruit. In 1964, Japan became the first Asian member country of a prestigious international development organisation-the Organisation for Economic Cooperation and Development (OECD). Since 1975, Japan has been the only Asian member country of the exclusive Group of Seven (G-7).

After the Second World War and throughout the Cold War period, Japan's adopted diplomatic strategy was maintaining close relations with Western countries, especially with the United States. Japan benefited from a 'special relation' with the United States since 1951 when Japan-US Security Treaty was signed. While the United States has been a guarantor of Japan's, and regional, security Japan was able to concentrate on the promotion of its own economic interests. To return the favour (on-gaeshi) to the US and, to some extent, as a 'burden sharing' Japan contributed financially for regional and global peace, stability and prosperity by providing economic assistance to developing countries and making donations to various international organizations. In this context, it does not come as surprise that Japan has become a major donor of foreign aid. At present, foreign aid giving 
is a pillar of Japanese diplomacy.

The end to the Cold War rendered the conceptual meaning of 'the West' ambiguous. A threat of communism that had for a long time cemented Japan's relations with the West dissipated and there remains no guarantee that Japan would always go along with Western countries' policies, especially the US policies, in the future. Samuel P. Huntington observed that with the end to the Cold War relations between Japan and the United States have grown increasingly difficult and cultural difference began to aggravate economic conflict. As he commented, "Here cultural difference exacerbates economic conflict" (Huntington 1993: 34).

Despite the fact that the US and Japan play complimentary roles in the international political arena, apparently, the two countries do not subscribe to the same set of values and norms and do not agree entirely with each other's foreign policies. For instance, in the 1990s, the US Government used extensively economic sanctions as a means to promote 'universal values,' such as human rights, democracy and freedom. Japan, on the other hand, despite the Japanese Government's pledge to use the country's aid power to promote the above values, has yet to show its commitment to the cause. Moreover, Japan has been criticised for its ambivalent attitude to the issues of human rights and democracy (Arase 1993).

The end to the ideological conflict between Western democracies and the Communist camp may help create an international environment where Japan is able to enjoy more autonomy to reinforce its relations with other Asian countries. As Tamamoto (1991: 579) notes, "Just as the Cold War divided Germany, it separated Japan and Asia. Now the end of the Cold War, coupled with Japan's paramount economic position in Asia, is pushing Tokyo toward assuming a much greater political role in the region."

Japan and its Asian neighbours have similar socio-cultural traditions and share common religious heritage. All of this may prove to be conducive to forging stronger ties between the countries of the region. Such a possibility has been suggested and commented upon before. As Ivan Hall put it, "Those in the West who attend to geo-cultural matters have long predicted the 'return' of Japan to its 'Asian roots,' and we now find the Japanese themselves proclaiming 'Re-Asianisation' of their country" (Hall 1994/1995: 19).

This paper intends to analyse historical pattern of East Asian integration by employing the 'flying geese' theory. There had been two attempts at regional integration in the recent history of East Asia. The first attempt took place in the years preceding the Second World War and during the war. At that time, Japan was forcing its leadership on other East Asian countries. The second bid for regional grouping occurred few decades later when Japan and other East Asian countries tried to establish a production network in the region. The paper poses the following questions: What were the main characteristics of the previous two attempts at East Asian integration? What factors led to the emergence and subsequent dispersal of the two 'flying geese' gaggles? What lessons could be drawn from those experiences?

Following the Introduction is a brief overview of the 'flying geese' model. The article then proceeds to highlight the general features of the first and second gaggles of 'flying geese.' It describes the process of their formation and factors that lead to the end of their 'flights.' The article focuses on Japan's ultra-nationalism that accompanied the formation of the first 'flying geese' gaggle and looks at the so-called 'Asian Values' discourse that accompanied the flight of the second gaggle of 'flying geese.' The article briefly reviews arguments and opinions of the present-day East Asian political and opinion leaders who deny the validity of 'Asian values' and show their support to universal values, such as human rights, democracy and freedom. Finally, this paper discusses Japan's place and role in the future regional groupings.

\section{The 'Flying Geese' Model}

In the 1930s, a Japanese economist, Kaname Akamatsu (1935) developed a multi-tier hierarchical 'flying geese' model to describe how industrialization spreads from developed countries to the developing countries. In a broader sense, this model might be applied to examine the patterns and characteristics of East Asian integration. In the 'flying geese' model of regional integration, Japan as the leading goose leads the second-tier geese (less developed countries) which, in their turn, are followed by the third-tier geese (least developed countries).

The most noticeable characteristic of the 'flying geese' pattern of East Asian regional integration is its hierarchical structure. Parties involved in this type of arrangement are not equal partners as there always is a dominant country- the 'leading goose'- that pilots the rest of the gaggle; the patron-client relationship is typical for this kind of organization. In this sense, the 'flying geese' organizational pattern can offer explanation for Japan's sense of superiority and its insistence to lead the rest of East Asia in the pre-war period and during the Second World War. As Pempel (1996/1997:16) points out, the "message to the rest of Asia was quite simple: follow Japan's example, stay in line, do not try to get too close, and eventually you too will fly into this kind of successful economy... . The implicit arrogance of a permanent place at the front of the avian Asian advance seems never to have been challenged."

Another important aspect of East Asian integration is that the apparent unison in which the flying geese progressed was maintained and reinforced through the use of power, i.e., military power in the case of the first gaggle of flying geese and economic power in the case of the second one. Emergence of the first gaggle of flying geese was due to Japan's invasion and occupation of its neighbouring countries. Though, for the sake of appearance, the Japanese military government declared that it was liberalizing Asia from Western colonialists and for this purpose the 'Greater East Asia Co-Prosperity Sphere' had been established. In the second half of the twentieth century, Japan 
used its economic power to establish through international trade, investment and foreign aid a sophisticated production network with other East Asian countries. Thus the second gaggle of flying geese came into existence.

\section{The First Gaggle of Flying Geese}

After the Meiji Restoration (1868), Japan re-established diplomatic relations with Western countries. Under a slogan Rich Economy and Strong Army, Japan began to modernize its economic mechanism and strengthen its military power. At the same time, in order to catch up with advanced countries Japan began subjugating its East Asian neighbours through the use of the military force.

\section{Formation of the First Gaggle of Flying Geese}

In order to survive in the harsh reality of imperialist competition, Japan started to expand its territory in the late nineteenth century. Before the Second World War, Taiwan, Korea and Manchuria were put under Japan's control. During the war, Japan proceeded to invade other parts of East Asia.

In this first attempt at Asian regional integration, Japan (the first-tier goose) suppressed the peoples of Taiwan, Korea and Manchuria (second-tier geese) and forced them to accept Japan's leadership as well as Japan's own ideals, values and socio-cultural norms. Japan unabashedly exploited those countries' natural and human resources. A similar type of suppressive relationship was maintained with the third-tier geese, i.e., Asian countries that Japan occupied during the Second World War.

\section{Main Characteristics of the First Gaggle of Flying Geese}

The main features of the first gaggle of flying geese are: 1) it was formed forcibly through the use of military force, 2) Japan aggressively promoted its own ideals and imposed those on other Asian countries.

In the decades leading to the Second World War, Japan adopted militarist and nationalist policies and espoused a strong anti-Western sentiment. Japan's extreme nationalism could be instrumental in fuelling the country's expansionist policy. As Buzan (1988: 557) commented, "There is no question that Japan's policy between 1895 and 1945 was aggressively expansionist and ruthlessly brutal." Tamamoto (1991: 583) maintains that proclamation of the 'Co-Prosperity Sphere' in East Asia was merely a justification for Japanese military expansion conducted under the pretence of liberalising Asia from the Western imperialism.

A strong sense of self-righteousness prevailed in Japan before and during the Second World War. Japanese political elite considered Japan's values and ideals superior to those of the rest of the world and was forcing them on other Asian countries. As Tamamoto wryly comments, "In the early $20^{\text {th }}$ century, as Japan began to feel more secure and confident with its modernisation successes, it awarded itself the right to civilise the rest of Asia... . And if it took force to impose upon Asia what was good, such was the burden of Japan's civilised mission" (Tamamoto 1991: 582).

\section{End of Flight}

The first gaggle of flying geese led by Japan ceased to exist when Japan surrendered to the Allied Forces in 1945. During the flight, Japan inflicted much damage on other Asian countries and in the end suffered from devastation and chaos that it had brought upon itself. Japan's economy was completely destroyed. Unemployment reached enormous proportions as many companies and businesses had gone bankrupt. Japan became one of the poorest countries in the world and relied on humanitarian assistance from Western countries. During the next few decades, Japan was fully concentrated on restoration and rehabilitation of its war-torn economy.

However disastrous the result, the fact remains that Japan's expansionist policy before and during the Second World War was the first attempt at Asian integration. As Pempel (1996/1997: 13) observes, "The only significant collective challenge to Western leadership in Asia, and the only real bid for Asian integration, came with Japan's unsuccessful military attempt during the 1930s to form the "Greater East Asia Co-Prosperity Sphere."

\section{The Second Gaggle of Flying Geese}

It took decades for Japan to restore its economy. In the process, the country shed its confrontational anti-Western stance. Furthermore, Japan renounced the use of military power in the international disputes by promulgating the 'peace constitution'. The Japan-US security pact gave Japan an opportunity to concentrate on pursuit of its own economic interests. More importantly, the huge US market has been vital for Japan's export-related industries.[ii] In order to bolster its increasing economic power, Japan embarked on creating a production network in East Asia, which, in effect, could be regarded as the second attempt at East Asian integration.

\section{Formation of the Second Gaggle of Flying Geese}

In the initial stage of the formation of the second gaggle of flying geese, Japan (the leading goose) exported manufactured goods to the second-tier geese, i.e., South Korea, Taiwan, Hong Kong and 
Singapore. All those countries later came to be known as Asian Newly Industrializing Economies (NIEs). Once local demand for imported goods in NIEs had reached a certain threshold, Japan proceeded to establish production bases there. In the next stage, Asian NIEs became able to produce internationally competitive products, while Japan assisted the NIEs' efforts of industrialization by providing them foreign aid. Eventually, Asian NIEs themselves became exporters of manufactured goods to other countries (third-tier geese), such as China and three ASEAN countries, namely Thailand, Malaysia and Indonesia. Besides exports, NIEs, following a pattern that had been established by Japan, were bringing investments to those countries. All the while, as had been the case with Asian NIEs, Japan assisted the third-tier geese's efforts to industrialize and modernize their economies by supplying them vast amounts of money as foreign aid.

Though there had been no formal declaration from Japan of its intention to form and lead another gaggle of flying geese, in terms of economic interdependence and production network, Japan had successfully carried out a de facto regional integration in Asia. [iii] As Dajin Peng (2000: 177) notes, "The regional production network in East Asia is a form of informal economic integration. It involves no formal institution or intergovernmental agreement but works according to a transnational logic."

\section{Main Characteristics of the Second Gaggle of Flying Geese}

The most prominent features of the second gaggle of flying geese are: 1) in the second bid for regional integration Japan relied solely on its economic power; 2) Japan employed its aid as a means to boost its economic power and consolidate its production network in East Asia and 3) the Japanese Government kept a low profile in international political affairs and was reluctant to come up with bold political initiatives.[iv]

First of all, after completing the rehabilitation of its economy, Japan adopted mercantilist policy and used its economic potential to lead other East Asian countries through establishing with them close economic relations and a highly efficacious production network. Japan was particularly successful in asserting the dominant economic position in ASEAN countries, or the third-tier geese. As Johan Saravanamuttu (1988: 9) observed, "Thus, the pattern of Japanese trade, aid and investment in ASEAN reveals an overall Japanese strategy of penetration in the region which generates ever greater economic dependence of ASEAN on Japan. The fact too is that the ASEAN countries, including Malaysia, have already turned to Japan for at least a decade during which Japan had rapidly established its economic hegemony over the region vis-à-vis other major economic blocs."

To facilitate Japanese companies' penetration of East Asian markets, the Japanese Government employed foreign aid as a tool. In the 1950s, Japan started reparation payments to East Asian countries that suffered from Japanese militarism during the Second World War. The Japanese Government was shrewd enough to use the reparation payments for Japan's own economic gain. As Miyashita (1999: 699) suggests, reparation payments were "designed primarily to help rebuild Japan's industrial capacity and re-establish economic ties with its wartime 'co-prosperity sphere' in Asia." Since the 1960s, Japan has been an important provider of foreign aid to Asia. However, these vast amounts of funds have been generally commercially motivated and used to cement and reinforce economic relations between Japan and its Asian neighbours. Katada (2002: 335) asserts that an important objective of Japan's aid to Asia has been "to solidify the hierarchy of the regional production network."

Second, after defeat in the Second World War, Japan turned into a reactive state reluctant to come up with bold political initiatives. As Calder (1988: 519-520) observed, "From the perspective of international relations theory, Japan is an especially interesting reactive state because of its enormous economic size, its substantial population (more than France's and West Germany's combined), and its pre-1945 history of pro-activism in the international system." In the post-war period, the Japanese Government assigned top priority to maintaining good relations with the US. Concern not to hurt its good ties with the US may be the reason why Japan did not back up the then Malaysian Prime Minister Mahathir Mohamad's idea to create a formal regional grouping-the East Asian Economic Caucus (EAEC)-and assume leadership of the organization. During the tour of Southeast Asia in 1993, the then Japanese Prime Minister Kiichi Miyazawa maintained that "US involvement and military presence in the Asia Pacific region were still necessary" and refrained from promising Japan's participation in the EAEC (Onozawa 1993: 277).

\section{End of Flight}

Japan was an energetic and tireless leader of the second gaggle of flying geese up to the end of the 1980 s when economic woes began to beleaguer the country. During the flight Japan had become a role model for aspiring Asian economies. In Malaysia, for example, the 'Look East' policy was introduced in the beginning of the 1980s to encourage the people and businesses to learn from the successful regional economies, such as Japan and South Korea. The then Malaysian Prime Minister Mahathir Mohamad (1988: 1) considered the Japanese management style and work ethics worth emulating. He stressed that "matters deserving attention was diligence and discipline in work, loyalty to the nation and to the enterprise or business where the worker is employed, priority of group over individual interests."

By the 1990s, the tide had changed. As Japan continued sliding ever deeper into economic recession, Japanese development model lost its attractiveness. It was regarded inadequate and subjected to harsh criticism. Robert Zielinski in the article "Role Model from Hell" even warned that Malaysia was headed for economic disaster unless it stopped emulating Japan. Zielinski (1998: 29) 
maintained that Malaysia went too far in pursuing the 'Look East' policy and was adopting not only the best of Japan, but its more negative traits as well. As he put it, "(Malaysia) imitated not only the frugal, hardworking Japan of the 1960s and '70s, but also the Japan of the bubble era."

While Japan had been loosing its energy to lead the region in the 1990s, the rest of the gaggle were able to continue their flight until the Asian economic crisis of 1997 put a stop to it. The end of the 'East Asian Miracle' in the late 1990s was also the end of flight for the second gaggle of flying geese. As Simon Tay (2002) commented, "Asian crisis has scattered the flock of geese that followed the Japanese model of development." More importantly, since the end of flight political and opinion leaders in East Asia were abandoning once widely popular 'Asian values' discourse.

\section{Japan's Role in Future East Asian I ntegration}

The end to the Cold War provides Japan a good opportunity to reappraise its role in international politics, take stock of its economic and diplomatic relations with East Asian countries, reassess the two previous attempts at regional integration and draw proper lessons from the past experiences. Japan may want to consider the following three diplomatic strategies to retain a place in future East Asian integration. First of all, Japan could contribute to dissipating the still lingering anti-Western sentiment in the region. For this, ultra-nationalist sentiment must be first checked within Japan's own borders. The Japanese Government may wish to be more active in promoting the 'universal values' of democracy, freedom and human rights in East Asia.

Second, Japan must continue nurturing good diplomatic relations with both Western countries and its Asian neighbours. By doing so, Japan may be able to assume a mediator's role between East Asia and the West, especially the United States, should any conflict or friction arise between the two regions. At the same time, the Japanese Government must promote the idea of an 'inclusive,' or 'open,' type of regional grouping since this will allow Japan to remain an active participant in the regional affairs and also may help establish closer and friendlier ties between Asian and Western countries.

Third, Japan should avoid the temptation to assume a self-appointed leadership of the region. Instead, Japan could concentrate on promoting a horizontal-structure regional organization where all members are on an equal footing.

\section{Conclusion}

Japan made the first attempt to lead neighbouring Asian countries before the Second World War. At that time, while conducting brutally expansionist policy, the Japanese Government maintained that it was liberalising Asia from Western imperialism. Japan embarked on creating the first flying geese gaggle by proclaiming the 'Greater East Asia Co-Prosperity Sphere.' Within the first flying geese gaggle Japan was forcefully imposing its own ideals and values. Japan's defeat in the war signified the end of flight for the first flying geese gaggle. It was also a very painful lesson for Japan not to embark on either isolationist or supremacist policies.

After the Second World War, Japan was fully concentrated on restoring its war-torn economy. In order to catch up with Western countries, Japan embarked on creating the second gaggle of flying geese through establishing a production network in East Asia.

All the while, Japan has been fostering close ties with Western countries, especially the US. While Japan (the 'first-tier goose') had been nurturing good ties with the West, the second- and third-tier geese proclaimed Asia's cultural supremacy over the West and put forward the 'Asian values' argument. The Asian economic crisis of 1997 interrupted the flight and put an end to the 'Asian values' debate. Overcoming this anti-Western attitude and helping to establish a regional grouping that would harmoniously co-exist with other regional groupings may prove to be the biggest challenge for Japan's Asia policy.

To meet this challenge, Japan must properly evaluate two previous attempts at regional integration. More importantly, Japan must candidly appraise the shortcomings of the first and second 'flying geese gaggles' and draw lessons from this experience. By doing this, Japan might be able to carve a niche for itself in the process of creating a new type of East Asian regional grouping that would be free of anti-Western sentiment and would uphold the universal values of human rights, democracy and freedom.

\section{Notes}

[i] The paper uses a broader definition of 'East Asia' that includes Northeast Asia and Southeast Asia.

[ii] Other East Asian countries followed Japan's example and exported their goods to the US. In other words, the vast US market has been a very important element for the region's economic development and the creation of a production network in the East Asia. 
beginning of the 1990s was one of them. "ASEAN Plus Three" and, more recently, "East Asian Community (EAC)" are other examples.

[iv] The formation of the second flying geese gaggle had apparently contributed to the economic development of such East Asian countries as Thailand, Malaysia and China as it stimulated the emergence of the new industries in those countries.

\section{References}

Akamatsu, Kaname 1935. 'Wagakuni yomo kogyohin no susei [Trend of Japanese Trade in Woollen Goods].' Shogyo Keizai Ronso [Journal of Nagoya Higher Commercial School] 13: 129-212.

Arase, David. 1993. 'Japanese Policy Toward Democracy and Human Rights in Asia.' Asian Survey 33 (10): 935-952.

Buzan, Barry 1988. 'Japan's Future: Old History Versus New Roles.' International Affairs 64(4): 557-573.

Calder, Kent E. 1988. 'Japanese Foreign Economic Policy Formation: Explaining the Reactive State.' World Politics 40(4): 517-548.

Fairclough, Gordon 1993. 'Standing Firm.' Far Eastern Economic Review, 15 April 1993: 21

Furuoka, Fumitaka 2002. 'Challenges for Japanese Diplomacy After the End of the Cold War.' Contemporary Southeast Asia 24(1): 68-81.

Hall, Ivan P. 1994/1995. 'Japan's Asia Card.' The National Interest 38: 19-27.

Huntington, Samuel P. 1993. 'The Clash of Civilisations?' Foreign Affairs 72(3): 22-49.

Katada, Saori N. 2002. 'Japan's Two-Track Aid Approach, The Forces Behind Competing Trends.' Asian Survey 42(2): $320-342$

Kuroyanagi, Yoneji 1995. 'Jinken Gaiko tai Eijian Uei [Human Rights Diplomacy and the Asian Way].' Kokusai Mondai 422: 31-45.

Mahathir, Mohamad 1988. 'New Government Policies.' In K.S. Jomo (ed). Mahathir's Economic Policy. (Kuala Lumpur: Insan 1988): 1-3.

Miyashita, Akitoshi 1999. 'Gaiatsu and Japan's Foreign Aid. Rethinking the Reactive-Proactive Debate.' International Studies Quarterly 43(4): 695-731.

Moody, Peter R. 1996. 'Asian Values.' Journal of International Affairs 50(1): 166-192.

Onozawa, Jun 1993. 'Japan and Malaysia: The EAEC Test of Commitment.' Japan Quarterly 40(3): 273-282.

Pempel, T.J. 1996/1997. 'Gulliver in Lilliput: Japan and Asian Economic Regionalism.' World Policy Journal 13 (4): $13-26$.

Peng, Dajin 2000. 'The Changing Nature of East Asia as an Economic Region.' Pacific Affairs 73(1): 171-191.

Saravanamuttu, Johan 1988. 'The Look East Policy and Japanese Economic Penetration in Malaysia.' In K.S. Jomo (ed). Mahathir's Economic Policy. Kuala Lumpur: Insan 1988: 4-28.

Tamamoto, Masaru 1991. 'Japan's Uncertain Role.' World Policy Journal 8(4): 579-597.

Tay, Simon 2001. 'Looking Beyond the Yasukuni Shrine Issue.' [accessed on 3 May 2002. $<$ http//www.asahi.com/English/asianet/column/eng_010921.html>

Zielinski, Robert. 'Role Model from Hell.' Time, 15 June 1998.

Fumitaka Furuoka is a lecturer at the School of Business and Economics, Universiti Malaysia Sabah. 
(C) 2005 Austrian Association of East Asian Studies 